NBER WORKING PAPER SERIES

EVASIVE SHAREHOLDER MEETINGS

David Yermack

Yuanzhi Li

Working Paper 19991

http://www.nber.org/papers/w19991

\author{
NATIONAL BUREAU OF ECONOMIC RESEARCH \\ 1050 Massachusetts Avenue \\ Cambridge, MA 02138 \\ March 2014
}

We appreciate helpful comments from Xi Li, Eric Roiter, Erin Smith, Ekkehard Wenger, and seminar participants at New York University. We thank Tumi Adebiyi for excellent research assistance. Part of this research was completed while Yermack was a visiting professor at Erasmus University Rotterdam. The views expressed herein are those of the authors and do not necessarily reflect the views of the National Bureau of Economic Research.

NBER working papers are circulated for discussion and comment purposes. They have not been peerreviewed or been subject to the review by the NBER Board of Directors that accompanies official NBER publications.

(C) 2014 by David Yermack and Yuanzhi Li. All rights reserved. Short sections of text, not to exceed two paragraphs, may be quoted without explicit permission provided that full credit, including $₫$ notice, is given to the source. 
Evasive Shareholder Meetings

David Yermack and Yuanzhi Li

NBER Working Paper No. 19991

March 2014, Updated June 2014

JEL No. G34,K22

\begin{abstract}
$\underline{\text { ABSTRACT }}$
We study the location and timing of annual shareholder meetings. When companies move their annual meetings a great distance from headquarters, they tend to announce disappointing earnings results and experience pronounced stock market underperformance in the months after the meeting. Companies appear to schedule meetings in remote locations when the managers have private, adverse information about future performance and wish to discourage scrutiny by shareholders, activists, and the media. However, shareholders do not appear to decode this signal, since the disclosure of meeting locations leads to little immediate stock price reaction. We find that voter participation drops when meetings are held at unusual hours, even though most voting is done electronically during a period of weeks before the meeting convenes.
\end{abstract}

David Yermack

Stern School of Business

New York University

44 West Fourth Street, Suite 9-160

New York, NY 10012

and NBER

dyermack@stern.nyu.edu

Yuanzhi Li

Temple University

Fox School of Business, Finance

Alter Hall 426

1801 Liacouras Walk

Philadelphia, PA 19122

yuanzhi.li@temple.edu 


\section{Evasive Shareholder Meetings}

\section{Introduction}

Corporate shareholder meetings are often portrayed as torpid affairs, consisting of uncontested elections and saccharine reports by managers who speak in hushed monotones. If a serious dispute exists about the composition of the board or other agenda items, the conflict is played out over weeks of negotiations and proxy voting prior to the meeting itself. During this pre-meeting period, shareholders electronically delegate their votes to one side or another or, more recently, might officially abstain or vote against management's nominees (Del Guercio, Seery, and Woidtke, 2008). Long before meeting day, the outcomes of most questions are known to both sides except in a small minority of cases (Cunat, Gine, and Guadalupe, 2012), so most meetings have low attendance and generate little news.

We propose a new method of examining the information content of shareholder meetings, by studying the implications of management's choices about where and when to hold them. Managers may want to deter meeting attendance by shareholders, the news media, and other groups for at least two distinct reasons. First, some meetings become the focus of theatrical protests and other publicity campaigns that are designed to generate unfavorable news coverage, and managers may want to increase the cost of these activities by scheduling meetings off-hours at faraway locations. Second, meetings almost always include an unscripted open microphone 
period during which shareholders (and sometimes others) have an opportunity to put questions to the management team. If the managers have unfavorable news that they wish to keep quiet, they would want to discourage attendance by those most likely to ask probing questions. Our research find abundant support for this second hidden information hypothesis.

We create a panel dataset that contains the locations, days of the week, and start times of nearly 10,000 annual meetings between 2006-10. We find a systematic pattern of poor company performance in the aftermath of annual meetings that are moved a great distance away from headquarters. Companies are more likely to announce unfavorable quarterly earnings in the aftermath of long-distance meetings, and these firms' stock prices significantly underperform market benchmarks over the six months following the meeting date. The results prove robust to a variety of alternative methods for identifying remote meetings, and the relationship between meeting distance and stock returns holds both for special meetings, which occur only infrequently, and also for annual meetings which occur every year at every company. We also find that details about the day and time off meetings have some impact on voter turnout and, to a lesser extent, the support received for certain ballot questions.

The impetus for our study is a recent encounter by one of the authors with a well-known European shareholder activist who attends many annual meetings. ${ }^{1}$ He asserted to us that he can reliably forecast poor future performance for companies when managers behave evasively during their shareholder meetings. This behavior might include answering questions incompletely, cutting short opportunities for shareholders to speak, refusing to recognize certain speakers, or

\footnotetext{
${ }^{1}$ Ekkehard Wenger is a member of the Association for the Advancement of Shareholder Democracy (Verein zur Förderung der Aktionärsdemokratie) in Germany and a professor of business administration, banking, and credit services at the University of Würzburg. For an English language profile of Wenger see The Economist, "The Outsider," June 3, 1995.
} 
excluding controversial items from the agenda. We test this conjecture by using the geography of meetings as a proxy for the evasiveness of management. While we cannot gauge managers' behavior at annual meetings by reading transcripts or observing their demeanor, we can easily examine their choices of meeting venues. ${ }^{2}$

Scheduling a meeting far from headquarters provides a straightforward opportunity for managers to discourage attendance. Research shows that firms tend to have high ownership in their local communities (Coval and Moskowitz, 1999) and that local analysts tend to forecast stock performance better than distant analysts (Malloy, 2005; Hong, Kubik, and Stein, 2005). A long-distance shareholder meeting would inevitably reduce participation from both of these cohorts as well as the local business press, who may be the most knowledgeable people about the company. Of course, many board members tend to be local as well (Knyazeva, Knyazeva and Masulis, 2013), and a far-away shareholder meeting also creates inconvenience for them.

We find little evidence that meetings are moved to distant locations when a firm has had a bad year, or when public information suggests that firms should expect confrontation; in fact, analysis of the agendas for the meetings in our sample suggests that companies are more likely to meet near headquarters when they expect hostile shareholder proposals or board elections that may be subject to protest voting. This may occur because the company is more comfortable arranging security, working with law enforcement, and controlling access to the meeting site in its own jurisdiction. Companies may also be relatively unconcerned with the publicity value of controversial agenda items, since these are known by everyone in advance and often have easily

\footnotetext{
${ }^{2}$ While we are not aware of any academic research into meeting locations, we have found one example from the popular media providing anecdotal evidence about this hypothesis. See Associated Press, "Companies take their shareholder meetings on the road when things get ugly," Syracuse Post-Standard, May 25, 2011.
} 
predictable outcomes.

Instead, we find that managers schedule long-distance meetings when the firm is experiencing adverse operating performance that is not already known to the market. Company stocks perform very poorly in the aftermath of remote meetings, and part of this result stems from disappointing quarterly earnings announcements following these meetings. By moving the meeting far away, the managers might forestall shareholder or news media questioning that could lead to the early disclosure of adverse news. Managers' tendency to delay bad news has been documented by studies such as Kothari, Shu and Wysocki (2009).

To date, most research into shareholder meetings has focused upon voting outcomes for director elections and other agenda items (see Yermack, 2010, for a survey). Two recent studies examine companies' release of information and stock price performance around meeting dates. Dimitrov and Jain (2011) find that companies tend to report favorable news in the period leading up to the meeting date, which results in an increasing stock price as the meeting approaches. The pattern then reverses after the meeting occurs, with the round-trip effect especially pronounced for companies with poor prior performance. Together these results imply that firms succeed in delaying bad news until after the meeting date, an interpretation consistent with our results. Supporting evidence appears in Banko et al. (2013), which finds that firms manipulate quarterly earnings with positive abnormal accruals in the two quarters prior to the annual meeting, followed by negative abnormal accruals in the subsequent quarter. These two studies identify aspects of governance such as institutional ownership and management entrenchment as predictors of this information distortion, but neither paper considers whether aspects of the meeting such as location, day, or time, coincide with managers' behavior. 
The remainder of this paper is organized as follows. Section 2 contains background information about the regulatory requirements for shareholder meetings and the potential motivation for moving a meeting to a distant location. Section 3 describes our dataset in detail. Section 4 includes statistical analysis of meeting outcomes and the associations between meeting locations and subsequent company performance and stock market returns. Section 5 concludes the paper.

\section{Shareholder meetings}

Shareholder meetings have played an indispensable role in corporate governance for hundreds of years. De Jongh (2011) writes about the shareholder meetings in the English East India Company dating from 1599. At these meetings, shareholders elected board members, received reports, and issued binding instructions to the managers. Corporate annual meetings today seem remarkably similar, providing a venue for companies to conduct formal business such as the election of directors, adoption of charter amendments, and approval of major transactions. They also play a cultural role in a corporation, giving shareholders an opportunity to meet managers face-to-face at least once a year, in order to receive information and ask questions. The main hypothesis in our paper is that, under certain conditions, firms will use geographic and scheduling strategies to minimize the opportunity for these encounters, while still going through the motions of complying with a centuries-old corporate norm.

No regulation requires managers or board members to appear in person at the annual meeting, but such attendance is all but mandatory under established corporate practices, and many companies have adopted bylaws or governance codes that require the board and top 
managers to attend. Only one company in recent memory, The Home Depot Inc., openly bucked this practice, convening an annual meeting in May 2006 with only Chairman and CEO Robert Nardelli in attendance and the rest of the board absent. The meeting was widely condemned in the press, ${ }^{3}$ and for Nardelli it proved to be his last as CEO, as he was ousted by his fellow directors the following January. Similarly, the open mic question time is not required by regulation, but by universal tradition it is included in virtually every shareholder meeting. Companies sometimes try to place restrictions on the question period and have been known to use other tactics to discourage potential speakers. For example, Wal-Mart Stores limited the entire question period to 15 minutes at its four-hour 2013 annual meeting, when it also obtained a temporary restraining order against labor unions and others in an attempt to pre-empt picketing at the meeting site. ${ }^{4}$ Bank of America at its 2012 annual meeting displayed a running timer on a video screen to limit each questioner to two minutes, after which a chime sounded and the microphone went dead. The company also brought several dozen police officers and security guards into the auditorium while hundreds of people protested its lending practices outside. ${ }^{5}$

For publicly traded companies, annual meetings are mandatory under a variety of overlapping state and federal laws and stock exchange listing regulations. Sometimes the requirements are indirect; for instance federal law requires the firm to schedule shareholder votes

\footnotetext{
${ }^{3}$ The Wall Street Journal ran a story with this quote from a pension fund official: "I've been doing this for 20 years, and it was the most anti-shareholder meeting I have seen." See Chad Terhune, "Home Depot's Critics Tear into Firm's Practices, Conduct," The Wall Street Journal, May 27, 2006. June 7, 2013.

${ }^{4}$ Alejandro Lazo, "Wal-Mart blocks protesters, announces \$15 billion share buyback," The Los Angeles Times,

5 Adam O’Daniel, “Activists 'mic-check' Bank of America CEO Brian Moynihan at annual meeting," Charlotte Business Journal, May 9, 2012.
} 
on such issues as executive compensation and advisory resolutions, and for convenience these usually occur at the annual meeting that would have already been convened to comply with stock exchange regulations for electing directors. Forty-eight of the 50 states' corporate law codes require a firm to hold annual meetings, but even in the two states that don't - Minnesota and North Dakota - a public company must schedule a meeting anyhow to comply with stock exchange and federal regulations. Further provisions of state and federal law require shareholder votes to approve transactions such as mergers and acquisitions and new equity issues, and these may occur at the annual meeting or, if time is of the essence, at a special or extraordinary meeting of shareholders. The Securities and Exchange Commission and the two major stock exchanges closely regulate the procedures for notifying shareholders of meetings, and their regulations also govern the process by which management and outsiders may solicit proxies from shareholders who do not wish to attend the meeting. In practice, the large majority of votes are cast by proxy. The tabulation of proxy votes is usually outsourced to a private firm (Kahan and Rock, 2008), and the proxy vote totals will be augmented by votes cast directly by shareholders who choose to attend the meeting. The mechanics and legitimacy of certain voting strategies such as "empty voting" have drawn great regulatory scrutiny in recent years (Hu and Black, 2006), although in principle these strategies should be unaffected by the scheduling issues studied in our paper.

Companies have great freedom to select the location, day of the week, and start time of their annual meetings. While a variety of regulations require that meetings must take place, the rules are largely silent about the logistical details. A company's bylaws may sometimes specify a recurring date or location for shareholder meetings each year, but usually the bylaws give the 
board of directors flexibility in choosing the site. As a typical example, Section 1.01 of the Bylaws of JPMorgan Chase \& Co. states that the annual meeting shall occur " . . at such time and place, if any, within or without the State of Delaware, as may be specified in the notice thereof, as shall be fixed by the Board of Directors of the Corporation." Many state laws provide a default policy under which shareholder meetings are presumed to take place at company headquarters unless the bylaws or board of directors decide otherwise. The rules for convening special meetings are quite similar, and just as flexible, as those for annual meetings. Abundant research shows that managers behave strategically when formulating the agendas for meetings (Bethel and Gillan, 2002), and that shareholders also act strategically in forming coalitions and deciding how to vote on certain ballot questions (Maug and Rydquist, 2009). The location and timing of meetings may interact with these strategic choices by managers and major shareholders, although we do not pursue these possibilities in this paper.

While meeting attendance can be small even for major corporations, cadres of activist investors and gadflies will often appear in the audience, many of them moving from one company meeting to another to promote agendas related to corporate governance and social policies or simply to heckle management. If the managers have bad news that they hope to keep quiet, avoiding discussion of the topic at a shareholder meeting may therefore be difficult, especially if the meeting occurs at a time and place convenient to these provocateurs. Certain members of this community, such as the Gilbert brothers, Evelyn Davis, and Wilma Soss, have acquired standout reputations and become known on sight to CEOs, who sometimes take actions 
to disarm them. ${ }^{6}$ Some of these activists take advantage of the SEC's rules that permit them to place questions on the annual meeting agenda, but others are more interested in asking questions directly to management during the open mic period. During this period, gadflies often make provocative statements about executive compensation, the company's environmental or employment policies, or political issues that involve the corporation. Encounters in this setting can become perilous for management teams that are not well prepared. For instance, McDonald's Corp.'s 2013 annual meeting received worldwide media coverage after a 9-year-old girl took the microphone and told the company's CEO, "it would be nice if you stopped trying to trick kids into wanting to eat your food all the time." The CEO's spontaneous response, that "we don't sell junk food," was ridiculed by commentators. ${ }^{7}$

\section{Data description}

We obtain our sample of shareholder meeting locations, dates, and times by downloading data from the Key Developments section of Standard \& Poor's CapitalIQ database. In the Key Development Situation field, CapitalIQ typically provides text copied directly from the headers of shareholder proxy statements that announce shareholder meetings. We use text functions to unpack these header fields and extract the relevant detail about each meeting, and we download

\footnotetext{
${ }^{6}$ An entertaining live blog of the 2010 Goldman Sachs Group Inc. annual meeting, including repeated encounters between Davis and CEO Lloyd Blankfein, can be found at http://blogs.wsj.com/deals/2010/05/07/live-blogging-goldman-sachs-shareholder-meeting/. Calling for Blankfein's resignation, Davis states, "A once great company is going to shame . . Goldman Sachs has become a nest of nepotism." She then asks Blankfein to resign, saying "You're not as smart as you look," to which the CEO replies, "That's the nicest thing you ever said to me." Both comments draw laughter, as well as news coverage.

7 See, for example, Lisa Suhay, “'We don't sell junk food:' McDonald's CEO's comment sparks backlash against 9-year-old," The Christian Science Monitor, May 30, 2013.
} 
each firm's headquarters address as well. CapitalIQ provides extremely broad coverage of public, private, and international companies as well as investment funds, and we apply some basic screens to the data: we retain only companies that are incorporated and headquartered in the United States and listed on either of the major stock exchanges; the latter restriction permits us to match our sample firms to stock returns data from the CRSP database. We delete investment companies, closed-end funds, and similar entities. We clean the CapitalIQ data by deleting duplicate observations, editing incomplete or clearly erroneous data, and checking outliers and obvious mistakes such as meetings that are reported to take place in the middle of the night. Much of our analysis uses the distance between headquarters and the meeting location as an important variable, and we calculate these distances using postal ZIP codes.

We merge the information about shareholder meetings from CapitalIQ with agenda and voting data from the ISS Voting Analytics Corporate Voting Database, using a five-year sample period that includes all meetings held between January 1, 2006, and December 31, 2010. Voting Analytics covers Russell 3000 firms, and this merge reduces our CapitalIQ sample by about $40 \%$ (most of these firms would also have dropped out due to our separate matching with CRSP stock return data). We end our sample in 2010 for two reasons: we have access to a cleaned version of the Voting Analytics database ending in 2010 provided to us by Smith (2013), and in 2011 the agendas for U.S. shareholder meetings changed significantly with the advent of mandatory sayon-pay advisory voting on executive compensation as required by the Dodd-Frank Act. Say-onpay votes have considerably increased the intensity of pre-meeting engagement between managers and shareholders, and we expect that many companies would have begun reconsidering the organizational details of their shareholder meetings from 2011 and continued to do so up to 
now. This evolving process should provide the basis for separate research once enough time series of post-2011 observations has accumulated.

Our final sample for analysis includes 9,616 annual meetings held by 2,342 public companies between 2006-2010. Most companies appear in the sample five times, but some have fewer observations because they went public or were delisted during the sample period, and one firm has six annual meetings in five years due to a quirk in its corporate calendar. We augment our sample of annual meetings by also collecting information for 268 special or extraordinary shareholder meetings held by the same 2,342 firms between 2006-10. Figure 1 shows the distribution of our sample of annual meetings in calendar time. The large of meetings take place in a five-week period every year that begins in the last week of April and continues until the end of May, and this season represents a time of peak activity for shareholder activists, proxy advisors, and others connected to the voting process. Figure 2 displays the distribution of annual meetings according to days of the week and starting times. A large majority of meetings begin at 10:00 a.m. local time, and most are held on either Tuesday, Wednesday, or Thursday, but some do take place either very early or very late in the day, and a few occur on weekends or adjacent to legal holidays. For example, Actuant Corp., a \$1.4 billion machinery company, held its 2007 annual meeting at 8:00 a.m. on January 16, the day following the Martin Luther King holiday. The venue was a riverside inn in Napa, CA, more than 2,400 miles from its Milwaukee headquarters.

Table 1 presents descriptive statistics about the sample, and it shows that most shareholder meetings occur close to headquarters, with $71 \%$ taking place within five miles of the home office and another $16 \%$ occurring between 5 and 50 miles away. For special meetings, the 
tendency to meet near headquarters is slightly stronger. However, some meetings take place a great distance away, as the sample includes more than 800 annual meetings and 18 special meetings that are held more than 250 miles from headquarters. In addition to the distance from headquarters, we also tabulate the distance from the meeting location to the nearest FAA large hub airport, and Table 1 indicates that $29 \%$ of all annual meetings take place more than an hour's drive (50 miles) from a major airport. In addition 34 annual meetings and 1 special meeting take place outside the United States, often when firms have major overseas operations, ${ }^{8}$ and 18 annual meetings take advantage of a recent reform and do not meet in any physical location, instead convening online in virtual space.

As an example of a meeting held at a remote location, TRW Automotive Holdings, an auto parts manufacturer with a market capitalization of about $\$ 4$ billion, convened its May 14, 2007, annual meeting at the Renaissance Casa de Palmas Hotel in McAllen TX, at the Southern tip of the continental United States near the Mexican border. The meeting took place almost 1,400 miles from the company's headquarters outside Detroit, and more than 300 miles from the nearest major airport, Houston. In the previous year, its 2006 shareholder meeting had taken place in the Ritz Carlton - Battery Park in New York City, and in 2008, 2009, and 2010 the meeting returned to various luxury hotels in midtown Manhattan. In line with the results of this study, the company’s stock price fell from $\$ 38.97$ on the day of the 2007 annual meeting to $\$ 25.90$ six months later, a drop of 33\% during a period when the S\&P500 index fell just $2 \%$.

\footnotetext{
${ }^{8}$ Thirteen of these annual meetings take place in Canada, but most of the others occur in far-flung locations such as China, Costa Rica, the Czech Republic, Australia, and the Netherlands Antilles. One company, General Cable Corp., has a Kentucky headquarters but held its annual meetings in Spain, Costa Rica, and Germany at different times during our sample period.
} 
Companies exhibit considerable year-to-year persistence in their meeting locations. Of those firms that appear in the sample all five years, and $67 \%$ of these companies meet in the same location (identical distance from headquarters) every year. When looking at year-to-year location choices for the entire sample, the unconditional probability that a firm meets in the same location as the previous year is $84 \%$. For an especially interesting subsample, we identify several dozen cases in which companies engage in one-time deviations from an otherwise consistent meeting pattern, and this group provides the basis for certain empirical tests below. Some companies move their meeting every year as a matter of policy, with conglomerate firms convening at facilities that they own all over the country. General Electric Co. provides a good example of this type of scheduling. A review of 21 General Electric proxy statements between 1994 and 2014 shows that the company held annual meetings in 18 different locations during this period, some of them in major cities such as Atlanta and Chicago, but others in far-flung venues such as Greenville, SC, Erie, PA, and Waukesha, WI. Only once in 21 years, in 2006 in Philadelphia, did General Electric's shareholders meet anywhere remotely proximate to its Fairfield, CT, headquarters.

Inspection of our dataset allows us to rule out a number of straightforward motivations for relocating a firm's annual meeting away from headquarters. A "leisure" or "tourism" hypothesis would predict that firms schedule meetings in resort destinations, as is common with industry conventions. For instance, United Technologies held its 2009 annual meeting near Palm Beach, FL, where it has a helicopter factory, instead of its Hartford, CT, headquarters. Leisure destinations typically have hotels, meeting space, and offer opportunities for off-hours recreation and entertainment. However, we found that annual meetings only rarely occur at such 
destinations. Our database includes only a smattering of meetings in cities such as Las Vegas, New Orleans, and Honolulu, and the large majority of these are convened by companies with local headquarters. ${ }^{9}$ A second "Delaware" hypothesis predicts that firms might hold meetings in Wilmington, DE, due to the widespread practice of incorporating under Delaware law. In his heavily-cited account of annual meeting protocol written more than 60 years ago, Caplin (1951) writes that "the typical annual meeting of shareholders continues to be completely dominated by the man who has just gotten off the train at Wilmington, Delaware, carrying a little black bag filled with proxies solicited by the management." While many annual meetings seem to have occurred in Wilmington in the mid-20th century, ${ }^{10}$ in our sample we find very little evidence of firms meeting in Delaware unless they are headquartered nearby. We construct a simple transition matrix of the 50 states and the District of Columbia, and we compare the number of meetings held in each state against the number of companies with headquarters located in that state. Delaware has a modestly positive surplus of meetings, with 13 more meetings than predicted by physical headquarters locations out of our total sample of nearly 10,000. Leisure states like Louisiana and Hawaii have almost exactly the number of meetings predicted by headquarters locations, and Nevada surprisingly has one of the largest deficits, with 58 fewer meetings than expected. California (+55 meetings) and Washington, DC ( +45 meetings) attract the most net out-of-state meetings, while the largest net meeting deficits occur in New Jersey (-

\footnotetext{
${ }^{9}$ New York City hosts more annual meetings than any other location, and other urban tourist destinations like San Francisco and Los Angeles are also popular, but these locations seem to offer at least as much opportunity for business as for pleasure.

${ }^{10}$ Asking companies to hold their shareholder meetings near headquarters rather than in Wilmington appears to have been a priority for early shareholder activists such as the Gilbert brothers, who sued in federal court and won the right to have shareholder resolutions added to the annual meeting agenda in the landmark 1947 SEC v. Transamerica Corp. decision. See Fisch (2008) and Caplin (1951), who alludes to "meetings often held at places selected without much thought being given to shareholders' convenience."
} 
56 meetings) and Ohio (-67 meetings) as well as Nevada (-58 meetings). Many New Jersey firms choose to meet nearby in New York, but it is not obvious why so many companies headquartered in Nevada or Ohio choose to avoid meeting there.

We examine the agendas of the meetings in our sample to determine which ones exhibit the potential for conflict with shareholders in the form of a contested ballot provision that may attracting broad support. Director elections represent the most important items at most meetings, and we identify cases of contested director elections as those meetings in which shareholders nominate candidates for the board to compete head to head with management's nominees, or when management's nominees are not endorsed for election by Institutional Shareholder Services (ISS), a research organization that plays a powerful and somewhat controversial role and issuing voting recommendations that are widely followed by institutional investors; these nominees lacking ISS support face the prospect of a low vote total or even losing their seats if a firm has adopted majority voting in director elections. We find that contested director elections occur at more than $27 \%$ of all annual meetings in our sample. We also identify contested agenda items in the areas of executive compensation, corporate governance, and socially oriented shareholder proposals; our criteria for identifying a contested vote generally requires a management proposal not to be endorsed by ISS, or an outside shareholder proposal that does receive pre-meeting ISS support.

Table 2 presents information about voting patterns at the meetings in our sample. More than 55,000 candidates are nominated by management for board seats at our 9,616 meetings, and on average these candidates receive more than $94 \%$ of the vote and are elected $98 \%$ of the time, consistent with the data on director elections in Cai, Garner, and Walkling (2010). Executive 
compensation proposals, including increases in the authorized number of common shares, generally receive about $85 \%$ support, as do changes to corporate governance such as charter amendments or alterations to voting regulations, when management is the proponent. However, the lack of an ISS endorsement is associated with much lower vote totals for these agenda items and, in the case of governance provisions, a materially lower pass rate, though it is not clear from the table whether ISS's recommendations are correlated with other data that may independently influence voters (see Choi, Fisch and Kahan, 2010). Shareholder proposals in these areas and shareholder board nominations generally receive much lower vote totals than management's proposals, with ISS support of shareholders appearing to have a modestly positive impact.

\section{Analysis}

In this section we present our analysis of the associations between annual meeting locations and start times, and subsequent company disclosures and stock returns.

\subsection{Choice of annual meeting venue}

We begin by investigating a company's choice of where to locate its annual meeting. We undertake this analysis due to the possibility that companies relocate their meetings for reasons that may also affect their subsequent stock price performance, such as major disagreements with shareholders or other constituencies that manifest themselves in the form of contested agenda items at the meeting.

Regression analysis of the meeting location choice appears in Table 3. We study four separate dependent variables: the meeting's distance from corporate headquarters, in log form; 
the meeting's distance from the nearest large hub airport, also in logs; a binary variable for whether the meeting occurs at a remote location, which we define as more than 50 miles from headquarters and 50 miles from a major airport (340 observations out of 9,616); and a binary variable for whether the meeting occurs at an exceptional location. For the last category, we examine only those firms that appear in the sample all five years, and we create an indicator variable equal to one if the firm holds its annual meeting more than 150 miles from headquarters one year out of the five, with its meetings taking place near headquarters every other year. This subsample of exceptional meetings includes 46 observations, all of which are at least 157 miles from headquarters, with a mean distance of 1,239 miles and a median of 1,048 miles. ${ }^{11}$ In estimations using this variable in Table 3 and Table 4, we include only those firms that appear in the sample for all five years. All four of the distance variables ignore the 18 Internet on-line meetings and 34 international meetings in our sample; we treat these categories separately, including them in certain regressions with indicator variables, and excluding them from other regressions to focus only on U.S.-based meetings.

In Table 3 we regress our four location variables against firm size, measured as the log of sales; the abnormal stock return in the prior fiscal year, equal to the raw return minus the CRSP value-weighted index; the four variables described above that capture contested ballot items at the annual meeting; and three corporate governance variables: institutional ownership, dual-class equity structure, and classified board. We download institutional ownership data from the

${ }^{11}$ As an example, in May 2006 KeyCorp, a regional banking company, held its annual meeting at an art museum in Portland, ME, the only time in the last 10 years that the company did not meet in the vicinity of its Cleveland headquarters. Consistent with the results in this paper, KeyCorp's stock underperformed the S\&P500 Index by $-3.7 \%$ in the six months subsequent to this meeting. 
Thomson Reuters Stock Ownership Summary database, and our sample observations have a mean value of $70.2 \%$ with 210 missing values, about $2 \%$ of the sample. For a few cases in which Thomson reports institutional ownership above $100 \%$, we truncate the value to this level. We obtain dual-class ownership data from Erin Smith, who hand-collected the information for use in Smith (2013). About $4.4 \%$ of our sample firms have more than one class of voting stock. We identify firms with classified boards by reading the agenda items for each meeting. Those firms with classified boards generally elect individual directors every third year and identify them as belonging to a group within the board that might be labeled class 1 , class 2 , or class 3 . Other companies with classified boards can be identified when a ballot proposal is docketed to consider declassifying the board. Through these methods, and by reading certain firms' proxy statements in more detail, we are able to create a classified board indicator that has a mean value of $52.3 \%$. For the regression estimates shown in Table 3, we omit Internet and international shareholder meetings in the first three columns. The two distance models shown on the left of the table are estimated in least squares, and the two binary variable models shown on the right of the table are estimated in logit. All models have standard errors clustered at the firm level and include month indicator variables, save for the exceptional meetings estimation on the right, which has too few positive observations to accommodate the month variables. The month indicators capture the seasonality of the annual meeting calendar (see Figure 1) as well as differences in weather and travel that may affect meeting participation.

The estimates in Table 3 suggest that larger firms are more likely to move their meetings far from headquarters, a result that seems logical since the relocation probably involves additional expense that would not be borne as easily by a smaller firm. However, the table 
includes very little evidence that firms relocate their annual meetings in response to poor prior performance or in anticipation of contested votes at the meeting. The abnormal return variable has a positive estimate in one model out of four, suggesting the firms move the meeting far from headquarters after enjoying good years rather than poor ones. Among the contested vote indicator variables, only five out of 16 coefficients have significant estimates, and four of these five are negative. This suggests that firms are more likely to meet close to home when they anticipate a contentious meeting. Corporate governance seems to play a role in the choice of meeting location. Firms with dual-class ownership structures and classified boards are less likely to move the meeting far from headquarters, a result that seems intuitive, since these companies are relatively immune from pressure from shareholder democracy. When institutional ownership is high, firms tend to locate the meeting near a major airport, implying that companies in rural locations may shift the meeting to a major city when pension funds and mutual funds populate the shareholder base. In all, the results in Table 3 seem surprising, because they give little indication that firms meet in far-away locations when they have performed badly, or expect a contentious meeting, or have bad corporate governance. To the contrary, most of the significant estimates associated with these variables lead to the opposite implication: firms that schedule long-distance meetings appear to be of larger size, better quality, with fewer takeover defenses, and no clear expectation of conflict in advance of the meeting.

\subsection{Stock performance following the annual meeting}

The central analysis of our paper appears in Table 4, which shows estimates for a standard four-factor model of expected stock returns. For each of the 9,616 company-year 
observations, we regress the daily stock returns against an intercept, the three widely used FamaFrench stock market factors, and the Carhart momentum factor. We include up to 252 daily observations for each firm, beginning the day following each year's annual shareholder meeting and continuing until either the date of the next year's meeting or the passage of 252 trading days (one calendar year), whichever comes first. If the firm is delisted before either of these dates, we include all observations up to the delisting date. We then augment each model by indicator variables that equal one during the six months (126 trading days) following each annual meeting. These indicators are then multiplied by each of the four distance variables introduced above in Table 3. We cluster standard errors for each company. Our choice of a six-month window for the interaction term is based on visual inspection of the abnormal returns, which seem to cumulate steadily over this period before bottoming out. For all Internet and overseas meetings we set the distance variables equal to zero.

As shown by the estimates in Table 4, companies that hold long-distance annual meetings experience subsequent abnormal returns that are negative, statistically significant, and of large magnitude. For example, the estimate in the first column of the table implies a daily abnormal return of -0.000043 times the log of the annual meeting's distance from headquarters. For example, following a meeting held 1,000 miles away from headquarters, a company's average cumulative return over the next six months would be:

$$
(-0.000043)(126) \ln (1,000)=-.037 \text { or }-3.7 \%
$$

In the second column, the variable measuring the distance from the meeting to a major airport has an estimate about half as large as the variable in the first column. In the third and fourth columns, the estimates for remote meetings and exceptional meetings are especially strong. For 
the 340 firms that hold remote meetings at least 50 miles from headquarters and at least 50 miles from a major airport, the average abnormal stock performance is $-6.8 \%$ over the next six months, and for the 46 firms that hold exceptional meetings, moving at least 150 miles away from headquarters only one time in a five-year cycle, those meetings are followed by average abnormal stock returns of $-11.7 \%$ over the next six months.

These results imply that when managers announce a distant location for an upcoming shareholder meeting, they must often have undisclosed information suggesting poor future performance. Moving the meeting may be part of a strategy to reduce attendance or forestall questioning from audience members, so that the chance is reduced for questions or confrontations that might force the managers to reveal what they know. The strong results in Table 4 imply that the market up to now has not internalized any such motivation of the managers; if their reasons for choosing a distant meeting location were transparent, then stock prices should fall sharply when these meeting locations are announced rather than gradually declining over a period of months after the meeting. We examine the proxy statement release dates for the companies in our sample and find no evidence of any significant reaction on these announcement dates, either for the sample as a whole or for the various subsamples of longdistance, remote, and exceptional meetings. Similarly, we find little unusual movement in company stock prices on the meeting dates themselves, either for the entire sample or for the relevant subsamples.

\subsection{Quarterly earnings announcements after shareholder meetings}

If companies badly underperform the market after holding long-distance annual meetings, 
then what goes wrong? We investigate the next quarterly earnings announcements released by our sample companies after their shareholder meetings. These may occur anywhere from 1 to approximately 90 days following the meeting, but they are made by all firms in the sample. Quarterly earnings are a useful event to study, because the information is always considered material by shareholders, and the announcements are mandatory and not subject to selection bias.

We use the IBES and CapitalIQ databases to identify the dates of earnings announcements following annual meetings, and we obtain coverage for 9,423 observations, or about $98 \%$ of the company-years in our sample. We test the favorability of these announcements using a standard market model event study over a two-day window including the announcement day and the next day; the two-day window accounts for the possibility of earnings announcements occurring after the closing of the stock market on the announcement day. As shown in the first line of Table 5, the mean abnormal return after the quarterly earnings announcements for our sample firms is positive and significant at $+0.41 \%$.

The next four lines of Table 5 show the average abnormal returns for earnings announcements as a function of the annual meeting's distance from headquarters. The data show a monotonic pattern, with the most favorable announcements made by companies who hold annual meetings within five miles of headquarters. These firms' announcements result in an average abnormal return of $+0.55 \%$. In the next three cohorts, encompassing meetings up to 50 miles, up to 250 miles, and more than 250 miles from headquarters, the subsequent earnings announcements become increasingly adverse, according to the average shareholder reactions. The right part of the table tests the significance of the differences between the abnormal returns in each subsample, and the abnormal returns for the first group that holds its meetings close to 
the home office. The most long-distance meetings, occurring more than 250 miles from headquarters, are followed by the most negative average abnormal returns of $-0.21 \%$. All three subsamples have average abnormal returns significantly below the average for the cohort of firms holding their meetings within five miles of headquarters, and these differences are all significant below the $1 \%$ level. At the bottom of the table we find that remote meetings are followed by earnings announcements significantly worse than for meetings held near headquarters, and we find exceptionally negative mean returns $-2.24 \%$ for earnings announcements the follow exceptional meetings, those at which the company breaks its pattern of meeting near headquarters for one time only.

\subsection{Special meetings}

As a robustness test of our main results, we examine the location, agendas, and stock performance in the aftermath of extraordinary or special meetings of shareholders, which are usually called at the discretion of management. Special meetings occur only infrequently, in just 268 for the 9,616 fiscal years covered by our sample. Table 6 shows information about the ballot items at the special meetings in our sample. The table shows that special meetings are sometimes called to ratify mergers and acquisitions, but more typically involve the authorization of new shares of common stock or changes in corporate governance.

In Table 7, we repeat our abnormal returns analysis for annual meetings and apply the same method to estimate the returns over the six months following special shareholder meetings. We drop 34 companies for which the special meeting is a dissolution event related to an acquisition by another company. We use three of the four distance variables, all of the ones from 
Table 4 except for the exceptional meeting indicator (it is not intuitively possible to identify exceptional special meetings, since these meetings do not occur according to a predictable schedule, and arguably all special meetings could reasonably be described as exceptional). Again we obtain negative estimates for the distance variable, and they are statistically significant in two out of three cases.

The magnitudes of these two estimates, in the first and third columns of Table 7, are especially large. If a firm holds a special shareholder meeting 1,000 miles from headquarters, the estimate in the first column implies average underperformance of its shares on the order of $16.5 \%$ over the next 126 trading days or six months. If the meeting takes place at a remote location, more than 50 miles from headquarters and also more than 50 miles from a major airport, the average underperformance is approximately $-22.7 \%$ over the next six months. The evidence for special meetings therefore reinforces our findings for annual meetings, implying that the choice of a distant meeting location is heavily influenced by management's possession of adverse private information.

\subsection{Meeting days and times}

In addition to the information about meeting locations, we also examine the days of the week on which meetings take place, and the hours at which they convene. We find few if any significant relations between meeting days and times and subsequent stock price performance. However, we do find that the scheduling of meetings appears to influence voter participation, or turnout, as well as the fraction of votes cast in favor of management. Table 8 contains the relevant analysis. 
Table 8 shows regression models for two dependent variables: voter participation, or turnout, and the fraction of votes in favor of each agenda item. We calculate turnout as the sum of votes for and against a ballot item, plus abstentions, all divided by shares outstanding. The fraction of votes cast in favor of an item equals the votes for, divided by a denominator which can equal either shares outstanding, or votes cast, or votes cast less abstentions, depending on the rules of each firm. The sample includes approximately 66,000 agenda items at the annual meetings in our dataset. We exclude dual-class firms from the analysis because of the conceptual difficulty of calculating statistics such as voter turnout in such a setting. For both turnout and vote received, we estimate two regressions, with subsamples partitioned according to whether the observation exhibits institutional ownership above or below the sample median value of $74.57 \%$. Estimates in the top two rows of the table imply that turnout is higher in larger companies, and voter support in favor of generic ballot propositions is higher if the company has a good year. Our main variables of interest, however, are a series of indicator variables derived from the start time of meetings, the day of the week, the identity of the sponsor of a particular ballot question, and the type of item covered by each ballot question.

We find that voter turnout is affected by meeting start times, at least within the subsample of observations with lower levels of institutional investor ownership. Achieving a sufficient turnout level may be important, because sometimes voter turnout falls short of the quorum need to convene a board meeting and ratify a proposal. If a meeting occurs very early (before 9:00 a.m.) or very late (after 4:00 p.m.), voter turnout falls by $2 \%$ to $3 \%$. No such result seems to apply to firms with higher institutional ownership. We also find lower turnout when the distance from headquarters to the meeting is large or institutional ownership is lower. Participation 
appears to be highest for auditor ratification votes, followed by director elections, executive compensation proposals, and other governance proposals. Turnout also increases when ISS endorses a ballot item.

The voter turnout results seem surprising, because shareholder voting can take place electronically during a fairly lengthy period in the weeks before the meeting. Whether a meeting begins at dawn or a midnight, the large majority of shareholders might be expected to cast their votes well in advance, without any regard to the physical location of the meeting. One possible explanation, suggested by the discussion of voting-count in Kahan and Rock (2008), is that vote tabulators do not conscientiously record every vote if the election occurs either very early or very late in the day, simply because they may be understaffed at an unusual meeting time. It is also possible that some shareholders delay voting until the last minute and then forget to vote if the meeting takes place at an hour different than the typical starting time of 10:00 a.m. If management is mindful of this tendency and wishes to suppress turnout, then scheduling a meeting either very early or very late in the day might have such an effect.

While voter turnout may be influenced somewhat by irregular meeting times, less evidence exists that the proportion of votes in favor of an agenda item will depend upon the details of scheduling. In the right two columns of Table 8, regression estimates indicate that favorable vote totals are higher for weekend meetings and overseas meetings, for instance, but these categories are relatively rare. We do find only one significant estimate related to meeting start times, suggesting that votes against proposals are more likely if a meeting begins late in the day, and institutional investor ownership is high. ISS endorsement of an agenda item appears to boost both turnout and the favorable vote percentage, while institutional ownership leads to 
significantly higher turnout and fewer favorable votes.

\section{Conclusions}

In this paper we analyze the signals coveyed by companies' decisions about where and when to hold their shareholder meetings. We find a strong negative performance pattern in the aftermath of meetings scheduled far from corporate headquarters. Companies holding distant shareholder meetings underperform the market by substantial amounts in the six months following both annual meetings and special meetings. Firms' first earnings announcements after long-distance annual meetings tend fall short of investors' expectations, according to event study stock price evidence.

The poor performance of companies following long-distance meetings suggests that management knows adverse news when choosing the location of these meetings, and it may move them far from headquarters as part of a scheme to suppress negative news for as long as possible. While this motivation seems understandable, it is less obvious why shareholders fail to decode such an unambiguous signal at the time the meeting location is announced.

In addition to these performance results, we find that evidence that voter participation and the pattern of votes in favor of various proposals may also be influenced by meeting scheduling, especially in cases when firms depart significantly from the common practice of beginning meetings at 10:00 a.m.

Shareholder meetings can be important events at which critical corporate decisions are made and management sometimes faces challenges from the company's shareholders and other constituencies. Our analysis shows that these meetings generate rich detail for statistical 
analysis. Further research into shareholder meetings might examine attendance, duration, news coverage, transcripts of questions and answers, the strategic bundling of agenda items by management, and other related variables. 


\section{References}

Banko, John, Melissa B. Frye, Weishen Wang, and Ann Marie Whyte, 2013, Earnings management and annual general meetings: The role of managerial entrenchment, Financial Review 48, 259-282.

Bethel, Jennifer E., and Stuart L. Gillan, 2002 , The impact of the institutional and regulatory environment on shareholder voting, Financial Management, winter, 29-54.

Cai, Jie, Jacqueline L. Garner, and Ralph A. Walkling, 2009, Electing directors, Journal of Finance 64, 2389-2421.

Caplin, Mortimer H., 1951, Annual meetings and corporate democracy: The lawyer's role, Virgina Law Review 37, 653-697.

Choi, Stephen, Jill Fisch, and Marcel Kahan, 2010, The power of proxy advisors: Myth or reality? Emory Law Journal 59, 869-918.

Coval, Joshua D., and Tobias J. Moskowitz, 1999, Home bias at home: Local equity preference in domestic portfolios, Journal of Finance 54, 2045-2073.

Cunat, Vicente, Mireia Gine, and Maria Guadalupe, 2012, The vote is cast: The effect of corporate governance on shareholder value, Journal of Finance 62, 1943-1977.

De Jongh, Joahn M., 2011, Shareholder activists avant la lettre: The "complaining participants" in the Dutch East India Company, 1622-1625, in Jonathan G.S. Koppell ed., Origins of Shareholder Advocacy (New York: Palgrave Macmillan).

Del Guercio, Diane, Laura Seery, and Tracy Woidtke, 2008, Do boards pay attention when investor activists "just vote no"? Journal of Financial Economics 90, 84-103.

Dimitrov, Valentin, and Prem C. Jain, 2011, It's showtime: Do managers report better news before annual shareholder meetings? Journal of Accounting Research 49, 1193-1221.

Fisch, Jill, 2008, The Transamerica case, in Jonathan Macey ed., The Iconic Cases in Corporate Law (Thomson-West).

Hong, Harrison, Jeffrey D. Kubik, and Jeremy Stein, 2005, Thy neighbor's portfolio: Word-ofmouth effects in the holdings and trades of money managers, Journal of Finance 60, 2801-2824.

Hu, Henry T.C., and Bernard Black, 2006, The new vote buying: Empty voting and hidden (morphable) ownership, Southern California Law Review 79, 811-908. 
Kahan, Marcel, and Edward Rock, 2008, The hanging chads of corporate voting, Georgetown Law Journal 96, 1227-1281.

Knyazeva, Anzhela, Diana Knyazeva, and Ronald Masulis, 2013, The supply of local directors and board independence, Review of Financial Studies 26, 1561-1605.

Kothari, S.P., Susan Shu, and Peter D. Wycocki, 2009, Do managers withhold bad news? Journal of Accounting Research 47, 241-276.

Malloy, Christopher J., 2005, The geography of equity analysts, Journal of Finance 60, 719-755.

Maug, Ernst, and Kristian Rydqvist, 2009, Do shareholders vote strategically? Voting behavior, proposal screening, and majority rules, Review of Finance 13, 47-79.

Smith, Erin E., 2013, Do shareholders want less governance? unpublished manuscript, available at ssrn.com/abstract $=2303921$.

Yermack, David, 2010, Shareholder voting and corporate governance, Annual Review of Financial Economics 2, 103-125. 


\section{Table 1}

\section{Descriptive statistics}

The table shows descriptive statistics for 9,616 annual and 268 special shareholder meetings held by 2,342 U.S. public companies between 2006 and 2010. Location data relative to headquarters is not tabulated for online and overseas meetings. The indicator for contested board votes equals one if at least one management nominee for the board fails to receive a favorable endorsement from Institutional Shareholder Services (ISS), or if shareholders nominate at least one hostile board candidate as part of a proxy fight. The indicator for contested compensation votes equals one if at least one management proposal on executive compensation or common share increase fails to receive an endorsement from ISS, or if at least one outside shareholder proposal on executive compensation does receive support from ISS. The indicator for contested governance vote equals one if at least one shareholder resolution on board structure, voting, or related matters is opposed by management but does receive an endorsement from ISS. The indicator for contested social proposal equals one if at least one shareholder resolution on the corporation's labor, humans rights, or other social policies is opposed by management but does receive support from ISS. The indicator for contested merger \& acquisition equals one if at least one vote to approve a corporate control transactions does not receive an endorsement from ISS. The indicator for contested equity issue equals one if a management proposal for a private placement, creation of a new security class, or a related transaction does not receive a support from ISS. Information about individual shareholder meetings is obtained from CapitalIQ (time and place) and Voting Analytics (agenda items and ISS endorsements). 
Number of unique firms

Number of shareholder meetings

Monday

Tuesday

Wednesday

Thursday

Friday

Saturday

Weekdays prior to legal holidays

Legal holidays

Weekdays following legal holidays

Less than 5 miles from headquarters

Between 5 and 50 miles from headquarters

Between 50 and 250 miles from headquarters

More than 250 miles from headquarters

More than 50 miles from nearest major airport

Online virtual meetings

Overseas meetings

Meetings with contested board vote

Meetings with contested compensation vote

Meetings with contested governance vote

Meetings with contested social proposal

Meetings with contested merger \& acquisition

Meetings with contested equity issue
Annual meetings

\begin{tabular}{rrrr} 
Number & Frequency & Number & Frequency \\
\hline 2,342 & & 2,342 & \\
9,616 & $100.0 \%$ & 268 & $100 \%$ \\
611 & & & \\
2,365 & $6.4 \%$ & 39 & $14.6 \%$ \\
2,582 & $24.6 \%$ & 71 & $26.5 \%$ \\
3,020 & $26.9 \%$ & 50 & $18.7 \%$ \\
1,020 & $31.4 \%$ & 58 & $21.6 \%$ \\
18 & $10.6 \%$ & 50 & $18.7 \%$ \\
102 & $0.2 \%$ & 0 & \\
2 & $1.1 \%$ & 6 & $2.2 \%$ \\
60 & $0.02 \%$ & 1 & $0.4 \%$ \\
& $0.6 \%$ & 1 & $0.4 \%$ \\
6,815 & $70.9 \%$ & 208 & $77.6 \%$ \\
1,577 & $16.4 \%$ & 37 & $13.8 \%$ \\
350 & $3.6 \%$ & 4 & $1.5 \%$ \\
822 & $8.5 \%$ & 18 & $6.7 \%$ \\
2,822 & $29.3 \%$ & 76 & $28.4 \%$ \\
18 & $0.2 \%$ & 0 & \\
34 & $0.4 \%$ & 1 & $0.4 \%$ \\
2,654 & $27.6 \%$ & 10 & $3.7 \%$ \\
1,130 & $11.8 \%$ & 26 & $9.7 \%$ \\
845 & $8.8 \%$ & 32 & $11.9 \%$ \\
199 & $2.1 \%$ & 0 & \\
5 & $0.05 \%$ & 3 & $1.1 \%$ \\
43 & $0.4 \%$ & 18 & $6.7 \%$
\end{tabular}


Table 2

Annual meeting votes

The table presents a summary of ballot items in a sample of 9,616 annual shareholder meetings held by 2,342 U.S. public companies between 2006 and 2010. The left half of the table shows the average vote totals and passage frequency for all agenda items. The right half of the table shows the same information for the subset of agenda items for which Institutional Shareholder Services (ISS) fails to issue a voting recommendation in support of management's position.

\begin{tabular}{llcccccc} 
& & \multicolumn{3}{c}{ Full sample } & & \multicolumn{2}{c}{ ISS not supporting management } \\
Type of vote & Proponent & Obs. & Avg. vote & Pass rate & Obs. & Avg. vote & Pass rate \\
Board nominations & Management & 55,288 & $94.4 \%$ & $98.7 \%$ & 6,656 & $79.2 \%$ & $98.5 \%$ \\
Board nominations & Shareholders & 195 & $68.7 \%$ & $63.1 \%$ & 58 & $84.0 \%$ & $87.9 \%$ \\
& & & & & & & \\
Auditor ratifications & Management & 8,312 & $98.5 \%$ & $98.7 \%$ & 51 & $94.3 \%$ & $96.1 \%$ \\
Compensation plans & Management & 5,347 & $85.4 \%$ & $97.8 \%$ & 908 & $71.5 \%$ & $92.1 \%$ \\
Governance changes & Management & 946 & $85.3 \%$ & $90.2 \%$ & 107 & $66.0 \%$ & $64.5 \%$ \\
& & & & & & & \\
Compensation resolutions & Shareholders & 560 & $31.9 \%$ & $7.7 \%$ & 409 & $39.2 \%$ & $9.8 \%$ \\
Governance resolutions & Shareholders & 1,291 & $43.1 \%$ & $34.0 \%$ & 1,043 & $48.8 \%$ & $40.2 \%$ \\
Social policy resolutions & Shareholders & 924 & $12.6 \%$ & $1.0 \%$ & 263 & $27.3 \%$ & $3.0 \%$
\end{tabular}




\section{Table 3}

\section{Determinants of annual meeting location relative to headquarters}

The table shows regression estimates of the choice of where to locate the company's annual shareholder meeting. The sample includes 9,616 meetings held by 2,342 U.S. public companies between 2006 and 2010. A limited number of observations are dropped due to missing sales or voting data, and overseas and online virtual meetings are excluded from the analysis in the first three columns. The fourth column includes only observations for those firms that appear in the sample all five years. The dependent variable in the left column equals the log of the distance between company headquarters and the annual meeting location, based upon ZIP codes. The dependent variable in the second column equals the log of the distance between the nearest major (large hub) airport and the annual meeting location. The dependent variable in the third column is an indicator that equals one if the annual meeting takes place at a remote location, more than 50 miles from headquarters and also more than 50 miles from the nearest major airport. The dependent variable in the right column is an indicator that equals one if the annual meeting takes place at an exceptional location, which occurs when the company holds the annual meeting in the vicinity of headquarters in four out of the five sample years, but shifts the meeting more than 150 miles away in the exceptional year. The prior year's abnormal return equals the shareholder return for the last fiscal year minus the return on the CRSP value-weighted stock index. The indicator for contested board votes equals one if at least one management nominee for the board fails to receive a favorable endorsement from Institutional Shareholder Services (ISS), or if shareholders nominate at least one hostile board candidate as part of a proxy fight. The indicator for contested compensation votes equals one if at least one management proposal on executive compensation or common share increase fails to receive an endorsement from ISS, or if at least one outside shareholder proposal on executive compensation does receive support from ISS. The indicator for contested governance vote equals one if at least one shareholder resolution on board structure, voting, or related matters is opposed by management but does receive an endorsement from ISS. The indicator for contested social proposal equals one if at least one shareholder resolution on the corporation's labor, humans rights, or other social policies is opposed by management but does receive support from ISS. Standard errors clustered at the firm level appear in parentheses below each estimate. 


\begin{tabular}{|c|c|c|c|c|}
\hline Dependent variable & $\begin{array}{r}\log (1+\mathrm{HQ} \\
\text { distance })\end{array}$ & $\begin{array}{r}\log (1+\text { apt. } \\
\text { distance })\end{array}$ & $\begin{array}{l}\text { Remote } \\
\text { location }\end{array}$ & $\begin{array}{r}\text { Exceptional } \\
\text { location }\end{array}$ \\
\hline Estimation & $\underline{\mathrm{OLS}}$ & $\underline{\mathrm{OLS}}$ & $\underline{\text { Logit }}$ & $\underline{\text { Logit }}$ \\
\hline Intercept & n.a. & n.a. & n.a. & $\begin{array}{r}-5.799^{* * *} \\
(1.069)\end{array}$ \\
\hline $\log ($ sales $)$ & $\begin{array}{c}0.096^{* * *} \\
(0.025)\end{array}$ & $\begin{array}{r}-0.015 \\
(0.019)\end{array}$ & $\begin{array}{c}0.185^{\text {*** }} \\
(0.055)\end{array}$ & $\begin{array}{l}-0.011 \\
(0.129)\end{array}$ \\
\hline Prior year abnormal return & $\begin{array}{l}0.100^{* *} \\
(0.042)\end{array}$ & $\begin{array}{r}0.003 \\
(0.030)\end{array}$ & $\begin{array}{r}-0.089 \\
(0.103)\end{array}$ & $\begin{array}{r}-0.340 \\
(0.345)\end{array}$ \\
\hline Contested board vote $(0,1)$ & $\begin{array}{r}0.095 \\
(0.067)\end{array}$ & $\begin{array}{r}-0.035 \\
(0.056)\end{array}$ & $\begin{array}{r}0.198 \\
(0.164)\end{array}$ & $\begin{array}{c}-0.814^{*} \\
(0.483)\end{array}$ \\
\hline Contested compensation vote $(0,1)$ & $\begin{array}{c}-0.138^{*} \\
(0.083)\end{array}$ & $\begin{array}{r}-0.046 \\
(0.065)\end{array}$ & $\begin{array}{r}-0.873^{* * *} \\
(0.246)\end{array}$ & $\begin{array}{r}0.644 \\
(0.408)\end{array}$ \\
\hline Contested governance vote $(0,1)$ & $\begin{array}{c}0.199^{*} \\
(0.121)\end{array}$ & $\begin{array}{c}-0.256^{* * *} \\
(0.090)\end{array}$ & $\begin{array}{r}-0.229 \\
(0.233)\end{array}$ & $\begin{array}{l}-0.944 \\
(0.783)\end{array}$ \\
\hline Contested social proposal $(0,1)$ & $\begin{array}{r}-0.242 \\
(0.215)\end{array}$ & $\begin{array}{r}0.006 \\
(0.195)\end{array}$ & $\begin{array}{r}0.102 \\
(0.386)\end{array}$ & $\begin{array}{r}0.027 \\
(1.136)\end{array}$ \\
\hline Institutional investor ownership (\%) & $\begin{array}{r}0.019 \\
(0.180)\end{array}$ & $\begin{array}{r}-0.648^{* * *} \\
(0.148)\end{array}$ & $\begin{array}{r}-0.424 \\
(0.448)\end{array}$ & $\begin{array}{r}1.084 \\
(0.689)\end{array}$ \\
\hline Dual class ownership structure $(0,1)$ & $\begin{array}{r}-0.244 \\
(0.185)\end{array}$ & $\begin{array}{r}0.231 \\
(0.178)\end{array}$ & $\begin{array}{r}-0.632^{* *} \\
(0.715)\end{array}$ & $\begin{array}{r}-12.778^{* * * *} \\
(0.227)\end{array}$ \\
\hline Classified board of directors $(0,1)$ & $\begin{array}{c}-0.288^{* * *} \\
(0.081)\end{array}$ & $\begin{array}{r}0.102 \\
(0.070)\end{array}$ & $\begin{array}{r}-0.385^{\text {** }} \\
(0.194)\end{array}$ & $\begin{array}{r}0.377 \\
(0.326)\end{array}$ \\
\hline Month indicator variables & Yes & Yes & Yes & No \\
\hline Observations & 9,041 & 9,041 & 9,041 & 6,504 \\
\hline Firms & 2,244 & 2,244 & 2,244 & 1,326 \\
\hline Number of cases & & & 308 & 44 \\
\hline $\begin{array}{l}R^{2} \\
\text { Likelihood ratio test statistic }\end{array}$ & 0.022 & 0.020 & $106.4^{* * *}$ & $16.2^{* *}$ \\
\hline
\end{tabular}

Significant at $1 \%(* * *), 5 \%(* *)$, and $10 \%(*)$ levels. 


\section{Table 4}

\section{Annual meeting location and subsequent performance of stock}

The table shows Fama-French four factor daily abnormal stock returns. The sample includes 2,342 U.S. public companies that hold 9,616 annual shareholder meetings between 2006 and 2010. The estimation includes up to one year (252 days) of stock returns following each shareholder meeting, with fewer returns included only if the firm is delisted or if the subsequent shareholder meeting occurs within one year. The key explanatory variables are an indicator for whether less than six months has elapsed since the prior annual meeting, times four variables related to that meeting's location. In the first column, the variable measures the distance between company headquarters and the annual meeting location, based upon ZIP codes. In the second column, the variable measures the distance from the nearest major airport to the annual meeting location. In the third column, an indicator variable equals one if the annual meeting takes place at a remote location, encompassing 340 meetings held more than 50 miles from headquarters and also more than 50 miles from the nearest major airport. In the fourth column, an indicator variable equals one if the annual meeting takes place at an exceptional location, encompassing 46 cases in which the company holds the meeting in the vicinity of headquarters in four out of the five sample years, but shifts the meeting more than 150 miles away in the exceptional year. The four distance variables are all set equal to zero for online virtual meetings (18 observations) and overseas meetings (34 observations), which are represented in the model by separate indicators. Meeting locations are obtained from shareholder proxy statements as recorded in CapitalIQ. Major airports include the 33 U.S. large hub airports that handle at least 1 percent of nationwide revenue passenger boardings. Stock return data is obtained from CRSP. The fourth column includes only observations for those firms that appear in the sample all five years. $t$ statistics clustered at the firm level appear in statistics below each estimate. 
Distance variable

Intercept

Market excess return

Small - large excess return

High - low excess return

Up - down excess return

Meeting within past six months $\mathrm{x}$ distance variable

Daily stock price observations

Firms

Annual meetings

Number of cases

$R^{2}$

Online and overseas meeting indicators

Significant at $1 \%(* * *), 5 \%(* *)$, and $10 \%(*)$ levels.

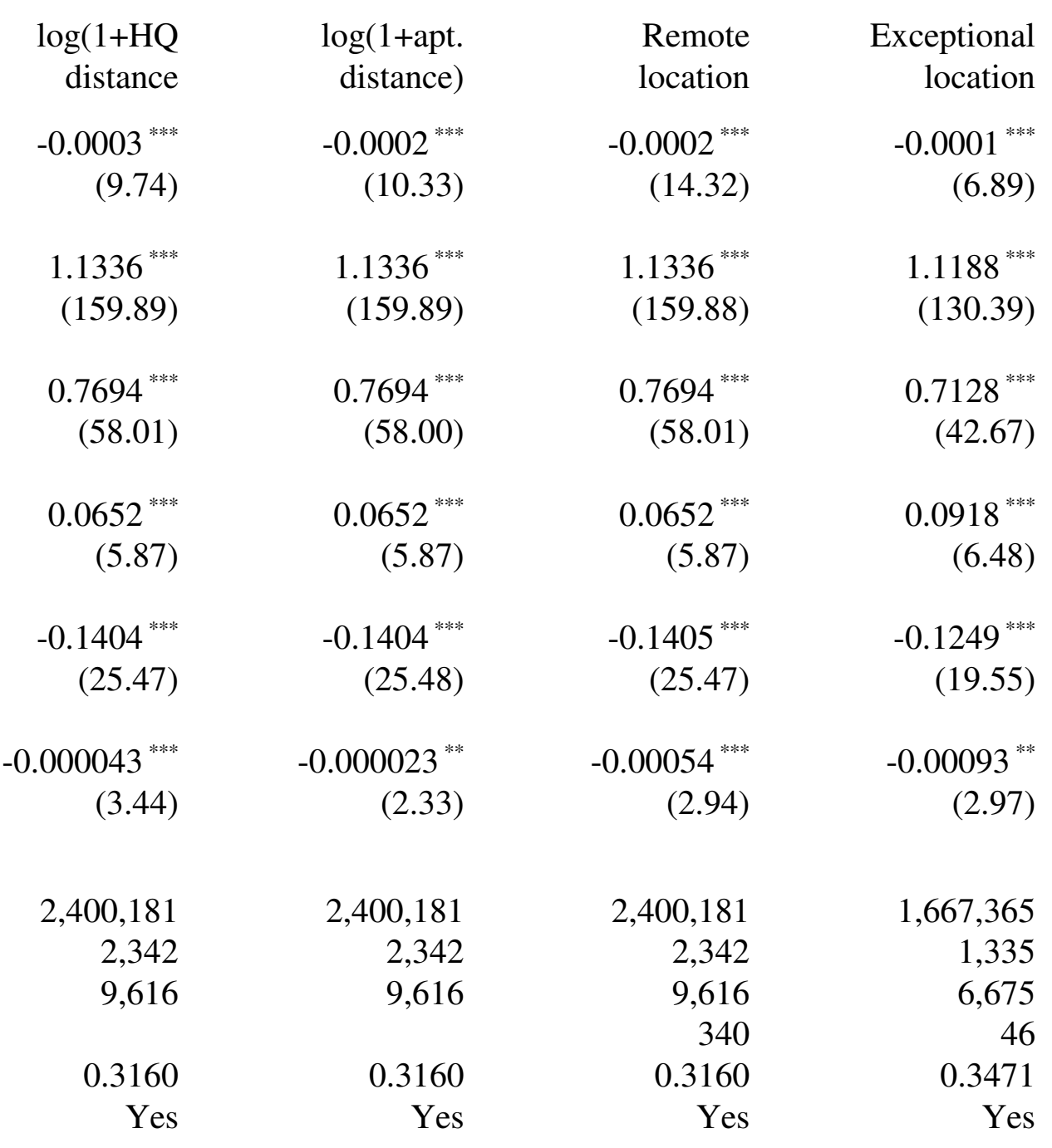




\section{Table 5}

\section{Stock price reactions to quarterly earnings announcements}

The table shows the abnormal stock returns accompanying quarterly earnings disclosures. The sample includes the first announcement made by each firm following its annual shareholder meeting, for a sample that includes 9,616 meetings held by 2,342 U.S. public companies between 2006 and 2010. Abnormal stock returns are cumulated over a two-day window including the earnings release day and the next day. Announcement dates are obtained from IBES and CapitalIQ, annual meeting dates and locations are obtained from CapitalIQ, and abnormal stock returns are calculated using standard market model methods. Missing values occur due to gaps in coverage for the two data sources, and lengthy omissions of earnings announcements by certain companies.

\begin{tabular}{|c|c|c|c|c|c|c|}
\hline & Observations & $\begin{array}{r}\mathrm{CAR}(0,1) \text { for } \\
\text { next earnings } \\
\text { ouncement after } \\
\text { annual meeting }\end{array}$ & & $\begin{array}{r}\text { Patel } \\
z \text {-statistic }\end{array}$ & $\begin{array}{r}\text { Difference } \\
\text { from CAR } \\
\text { for HQ } \\
\text { meetings }\end{array}$ & \\
\hline Full sample & 9,423 & $0.41 \%$ & $* * *$ & 11.09 & & \\
\hline Less than 5 miles from headquarters & 6,684 & $0.55 \%$ & $* * *$ & 12.09 & n.a. & \\
\hline Between 5 and 50 miles from headquarters & 1,536 & $0.20 \%$ & $* * *$ & 3.18 & $-0.35 \%$ & $* * *$ \\
\hline Between 50 and 250 miles from headquarters & 341 & $-0.08 \%$ & & -0.54 & $-0.63 \%$ & $* * *$ \\
\hline More than 250 miles from headquarters & 810 & $-0.21 \%$ & & -1.46 & $-0.76 \%$ & $* * *$ \\
\hline Online virtual meetings & 18 & $1.46 \%$ & $*$ & 1.85 & $0.91 \%$ & \\
\hline Overseas meetings & 34 & $0.44 \%$ & & 1.13 & $-0.11 \%$ & \\
\hline Remote meetings & 332 & $-0.18 \%$ & & 0.60 & $-0.73 \%$ & $* *$ \\
\hline Exceptional meetings & 46 & $-2.24 \%$ & $* * *$ & -4.02 & $-2.79 \%$ & $* * *$ \\
\hline
\end{tabular}

Significant at $1 \%(* * *), 5 \%(* *)$, and $10 \%(*)$ levels. 


\section{Table 6}

\section{Special meeting votes}

The table presents a summary of ballot items in a sample of 268 special shareholder meetings held by U.S. public companies between 2006 and 2010. The left half of the table shows the average vote totals and passage frequency for all agenda items. The right half of the table shows the same information for the subset of agenda items for which Institutional Shareholder Services (ISS) fails to issue a voting recommendation in support of management's position.

\begin{tabular}{llcccccc} 
& & \multicolumn{3}{c}{ Full sample } & & \multicolumn{2}{c}{ ISS not supporting management } \\
Type of vote & Proponent & Obs. & Avg. vote & Pass rate & Obs. & Avg. vote & Pass rate \\
Director nominations & Management & 69 & $79.6 \%$ & $85.5 \%$ & 23 & $55.4 \%$ & $65.2 \%$ \\
$\begin{array}{l}\text { Director nominations } \\
\text { Director removals }\end{array}$ & Shareholders & 12 & $73.4 \%$ & $33.3 \%$ & 4 & $94.2 \%$ & $50.0 \%$ \\
& Shareholders & 20 & $43.1 \%$ & $40.0 \%$ & 3 & $95.4 \%$ & $100.0 \%$ \\
M\&A transactions & Management & 93 & $85.1 \%$ & $94.6 \%$ & 4 & $62.1 \%$ & $75.0 \%$ \\
Compensation plans & Management & 144 & $76.4 \%$ & $92.4 \%$ & 28 & $72.9 \%$ & $85.7 \%$ \\
Governance changes & Management & 211 & $82.9 \%$ & $72.0 \%$ & 64 & $68.3 \%$ & $64.0 \%$ \\
Security issuance & Management & 93 & $88.1 \%$ & $91.4 \%$ & 18 & $65.8 \%$ & $88.9 \%$ \\
Governance resolutions & Shareholders & 9 & $39.0 \%$ & $11.1 \%$ & 3 & $43.7 \%$ & $33.3 \%$
\end{tabular}




\section{Table 7}

\section{Special meeting location and subsequent performance of stock}

The table shows Fama-French four factor daily abnormal stock returns. The sample includes 268 special or extraordinary shareholder meetings held by U.S. public companies between 2006 and 2010, but 34 firms are excluded from the regression analysis because they are delisted after an acquisition is approved by vote at the special meeting. The estimation includes up to one year (252 days) of stock returns following each shareholder meeting, with fewer returns included only if the firm is delisted or if the subsequent shareholder meeting occurs within one year. The key explanatory variables are an indicator for whether less than six months has elapsed since the special shareholder meeting, times three variables related to that meeting's location. In the first column, the variable measures the distance between company headquarters and the special meeting location, based upon ZIP codes. In the second column, the variable measures the distance from the nearest major airport to the special meeting location. In the third column, an indicator variable equals one if the special meeting takes place at a remote location, encompassing 7 special meetings held more than 50 miles from headquarters and also more than 50 miles from the nearest major airport. The three distance variables are all set equal to zero for one overseas special meeting, which is represented in the model by a separate indicator. Meeting locations are obtained from shareholder proxy statements as recorded in CapitalIQ. Major airports include the 33 U.S. large hub airports that handle at least 1 percent of nationwide revenue passenger boardings. Stock return data is obtained from CRSP. $t$-statistics clustered at the meeting level appear in statistics below each estimate. 


\begin{tabular}{|c|c|c|c|}
\hline Distance variable & $\begin{array}{r}\log (1+\mathrm{HQ} \\
\text { distance }\end{array}$ & $\begin{array}{r}\log (1+\text { apt. } \\
\text { distance })\end{array}$ & $\begin{array}{l}\text { Remote } \\
\text { location }\end{array}$ \\
\hline Intercept & $\begin{array}{r}-0.0008^{* * * *} \\
(5.04)\end{array}$ & $\begin{array}{r}-0.0008^{* * * *} \\
(4.43)\end{array}$ & $\begin{array}{r}-0.0008^{* * * *} \\
(5.68)\end{array}$ \\
\hline Market excess return & $\begin{array}{r}1.1181^{* * * *} \\
(32.95)\end{array}$ & $\begin{array}{r}1.1182^{* * * *} \\
(32.93)\end{array}$ & $\begin{array}{r}1.1181^{* * *} \\
(32.94)\end{array}$ \\
\hline Small - large excess return & $\begin{array}{r}0.8346^{* * * *} \\
(14.35)\end{array}$ & $\begin{array}{r}0.8346^{* * * *} \\
(14.35)\end{array}$ & $\begin{array}{r}0.8347^{* * * *} \\
(14.35)\end{array}$ \\
\hline High - low excess return & $\begin{array}{r}0.2941^{* * *} \\
(4.18)\end{array}$ & $\begin{array}{r}0.2939^{* * *} \\
(4.18)\end{array}$ & $\begin{array}{r}0.2938^{* * *} \\
(4.18)\end{array}$ \\
\hline Up - down excess return & $\begin{array}{r}-0.1604^{* * *} \\
(4.07)\end{array}$ & $\begin{array}{r}-0.1605^{* * *} \\
(4.07)\end{array}$ & $\begin{array}{r}-0.1608^{* * *} \\
(4.08)\end{array}$ \\
\hline $\begin{array}{l}\text { Meeting within past six months } \mathrm{x} \\
\text { distance variable }\end{array}$ & $\begin{array}{r}-0.00019^{*} \\
(1.83)\end{array}$ & $\begin{array}{r}-0.00004 \\
(0.55)\end{array}$ & $\begin{array}{r}-0.0018^{*} \\
(1.93)\end{array}$ \\
\hline Daily stock price observations & 58,905 & 58,905 & 58,905 \\
\hline Meetings & 234 & 234 & 234 \\
\hline Number of cases & & & 7 \\
\hline$R^{2}$ & 0.2616 & 0.2616 & 0.2616 \\
\hline Overseas meeting indicator & Yes & Yes & Yes \\
\hline
\end{tabular}

Significant at $1 \%(* * *), 5 \%(* *)$, and $10 \%(*)$ levels. 


\section{Table 8}

\section{Election turnout and outcomes}

The table shows ordinary least squares estimates of the voter turnout and votes received in a sample of 9,616 annual shareholder meetings held by 2,342 U.S. public companies between 2006 and 2010. Holiday weekend meetings include those on the weekdays immediately before and after public holidays or the adjacent weekends. Information about meeting times and locations is obtained from CapitalIQ, institutional investor ownership data is obtained from Thomson Reuters, and voting data, including Institutional Shareholder Services (ISS) recommendations, is obtained from Voting Analytics. Dual-class firms are excluded from the analysis. The table presents information for subsamples partitioned according to the sample median value of institutional investor ownership (74.55\%). $t$-statistics clustered at the meeting level appear in statistics below each estimate.

Dependent variable:

Institutional investor ownership:

$\log ($ sales $)$

Prior year abnormal return

Early meeting, before 9:00 a.m.

Lunch meeting, 12:00 or 1:00 p.m.

Late meeting, after 4:00 p.m.

Weekend

Holiday weekend
Voter turnout Above
median
$0.003^{* * *}$

0.001

0.005

(1.01)

$-0.001$

$-0.021$

(0.60)

$-0.085^{* * *}$

$0.015^{*}$ (1.67)
Below median

$0.008^{* * *}$

$$
0.003
$$

$0.007^{*}$

$$
-0.026^{* *}
$$

$0.005^{*}$

(1.70)

$-0.005$

$(0.52)$

0.002

(0.79)

0.002

(0.55)

(2.09)

(2.30)

$-0.010$

(0.38)

$0.032^{* *}$

(2.09)

$0.013^{* *}$

$$
0.020-0.013^{* * *}
$$

$-0.001$

(1.16)

(2.70)

(0.17) 


\begin{tabular}{|c|c|c|c|c|}
\hline Online virtual meeting & $\begin{array}{l}0.004 \\
(0.17)\end{array}$ & $\begin{array}{r}-0.007 \\
(0.25)\end{array}$ & $\begin{array}{r}-0.003 \\
(0.35)\end{array}$ & $\begin{array}{r}-0.022 \\
(0.81)\end{array}$ \\
\hline Overseas meeting & $\begin{array}{r}-0.037 \\
(0.64)\end{array}$ & $\begin{array}{l}0.002 \\
(0.07)\end{array}$ & $\begin{array}{l}0.015 \\
(1.12)\end{array}$ & $\begin{array}{r}0.040^{* * * *} \\
(3.49)\end{array}$ \\
\hline $\log (1+$ distance from headquarters $)$ & $\begin{array}{r}0.0001 \\
(0.08)\end{array}$ & $\begin{array}{r}-0.004^{* * *} \\
(2.87)\end{array}$ & $\begin{array}{r}-0.001^{*} \\
(1.65)\end{array}$ & $\begin{array}{r}-0.0002 \\
(0.68)\end{array}$ \\
\hline Institutional investor ownership (\%) & $\begin{array}{c}0.114^{* * *} \\
\quad(4.50)\end{array}$ & $\begin{array}{r}0.067^{* * *} \\
(3.75)\end{array}$ & $\begin{array}{l}0.014 \\
(1.33)\end{array}$ & $\begin{array}{r}-0.069^{* * *} \\
(12.87)\end{array}$ \\
\hline Management sponsored ballot item & $\begin{array}{r}0.045^{* *} \\
(2.08)\end{array}$ & $\begin{array}{c}0.060^{* * *} \\
(3.54)\end{array}$ & $\begin{array}{c}0.331^{* * *} \\
(14.42)\end{array}$ & $\begin{array}{r}0.468^{* * *} \\
(37.19)\end{array}$ \\
\hline ISS support indicator & $\begin{array}{r}0.046^{\text {**** }} \\
\quad(7.98)\end{array}$ & $\begin{array}{r}0.021^{* * *} \\
\quad(3.58)\end{array}$ & $\begin{array}{c}0.242^{\text {**** }} \\
(38.81)\end{array}$ & $\begin{array}{r}0.161^{* * * *} \\
(41.96)\end{array}$ \\
\hline Board election indicator & $\begin{array}{r}0.133^{* * *} \\
\quad(8.22)\end{array}$ & $\begin{array}{r}0.139^{* * *} \\
(8.86)\end{array}$ & $\begin{array}{r}0.097^{\text {**** }} \\
(6.38)\end{array}$ & $\begin{array}{r}0.065^{\text {**** }} \\
\quad(5.26)\end{array}$ \\
\hline Auditor ratification indicator & $\begin{array}{c}0.150^{* * *} \\
(9.38)\end{array}$ & $\begin{array}{c}0.175^{* * *} \\
(11.37)\end{array}$ & $\begin{array}{r}0.120^{\text {**** }} \\
(7.95)\end{array}$ & $\begin{array}{r}0.084^{\text {**** }} \\
\quad(7.53)\end{array}$ \\
\hline Compensation plan or policy indicator & $\begin{array}{r}0.077^{\text {**** }} \\
\quad(5.22)\end{array}$ & $\begin{array}{r}0.062^{* * *} \\
(4.63)\end{array}$ & $\begin{array}{r}-0.007 \\
(0.49)\end{array}$ & $\begin{array}{r}-0.022^{* *} \\
(2.13)\end{array}$ \\
\hline Shareholder social proposal indicator & $\begin{array}{r}0.108^{* * *} \\
\quad(5.93)\end{array}$ & $\begin{array}{c}0.058^{* * *} \\
\quad(3.17)\end{array}$ & $\begin{array}{r}-0.230^{\text {*** }} \\
(13.78)\end{array}$ & $\begin{array}{r}-0.194^{* * * *} \\
(18.04)\end{array}$ \\
\hline Observations & 33,473 & 33,264 & 32,959 & 32,649 \\
\hline Mean of dependent variable & $85.61 \%$ & $81.47 \%$ & $91.39 \%$ & $91.23 \%$ \\
\hline Month indicator variables & Yes & Yes & Yes & Yes \\
\hline $\mathrm{R} 2$ & 0.079 & 0.051 & 0.749 & 0.776 \\
\hline
\end{tabular}

Significant at $1 \%(* * *), 5 \%(* *)$, and $10 \%(*)$ levels. 


\section{Figure 1}

\section{Dates of annual meetings}

The figure shows the dates of 9,616 annual shareholder meetings held by 2,342 U.S. public companies between 2006 and 2010.
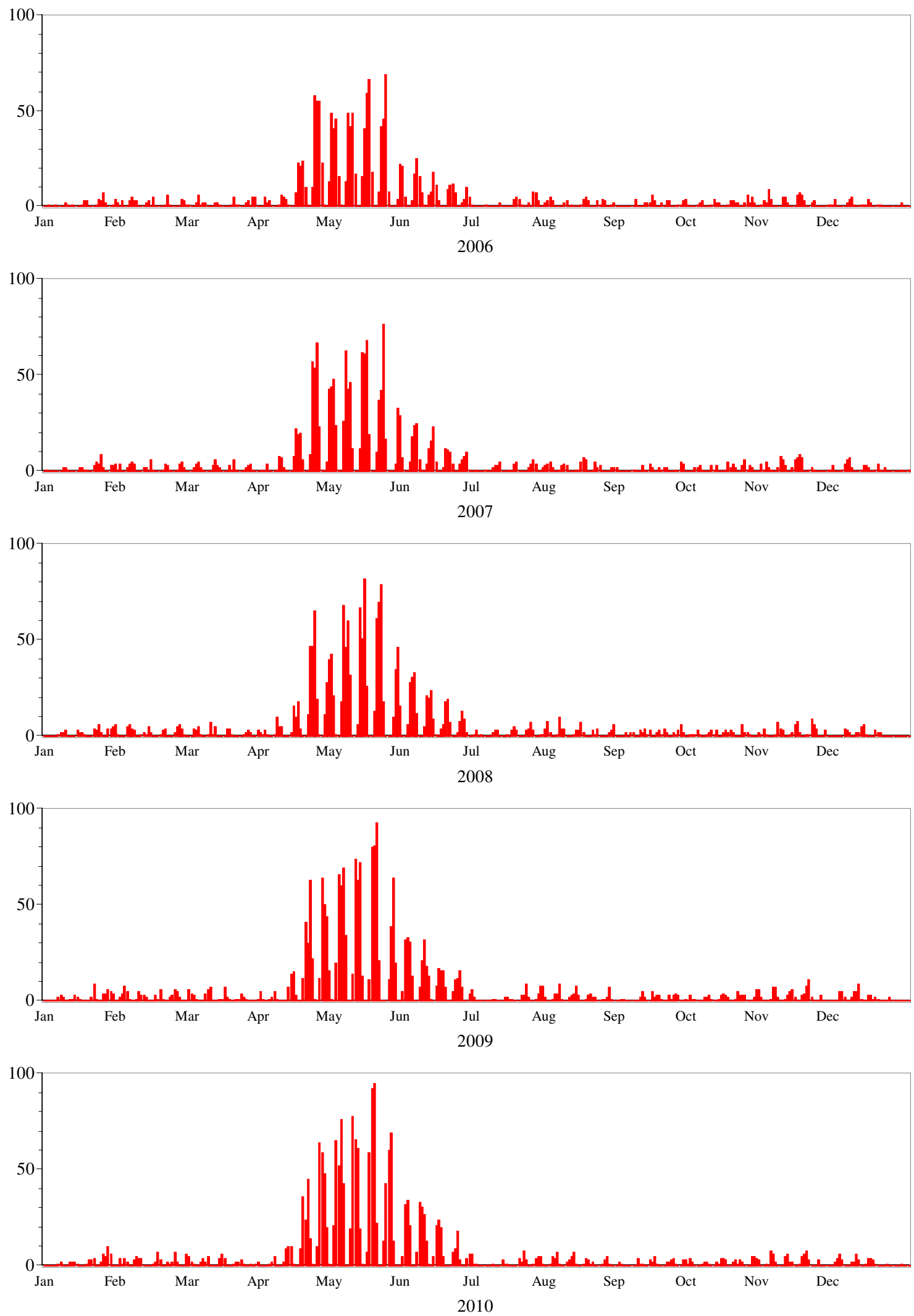


\section{Figure 2}

Days and starting times of annual meetings

The figure shows the days of the week and starting times for 9,616 annual shareholder meetings held by 2,342 U.S. public companies between 2006 and 2010.

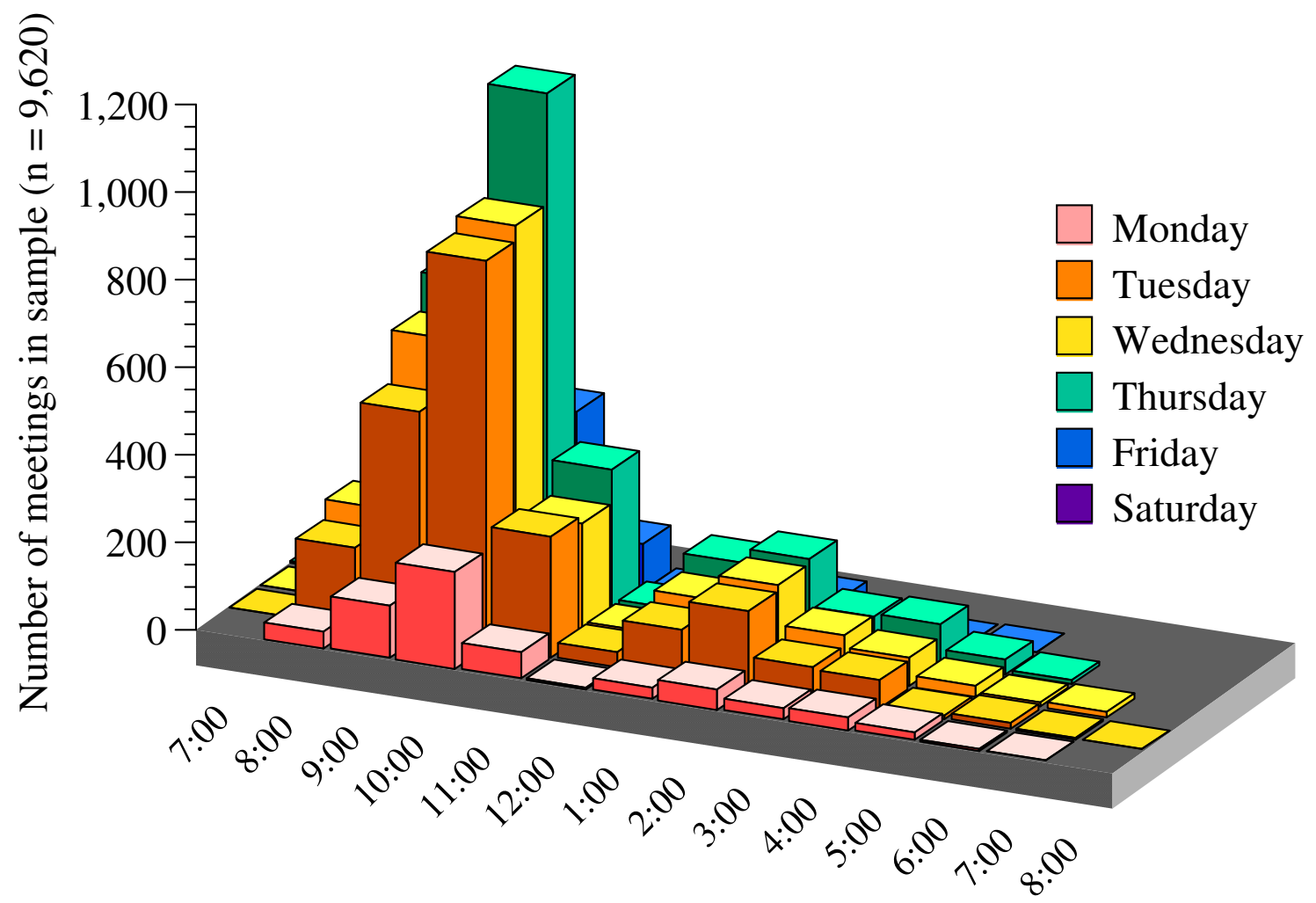

Starting time 